\title{
Delineation of Land Management Units in Tropical South Deccan Plateau of India
}

\author{
V. Ramamurthy ${ }^{1 *}$, K.M. Nair ${ }^{1}$, S.C. Ramesh Kumar ${ }^{1}$, S. Srinivas ${ }^{1}$, \\ L.G.K. Naidu ${ }^{1}$, K. Sujatha ${ }^{1}$, Dipak Sarkar ${ }^{2}$ and S.K.Singh ${ }^{2}$ \\ ${ }^{1}$ ICAR-National Bureau of Soil Survey and Land Use Planning, Regional centre, Hebbal, Bangalore-560 024, India \\ ${ }^{2}$ National Bureau of Soil Survey and Land Use Planning, Amravati road, Nagpur-440033, India
}

\begin{abstract}
Soils are highly variable spatially due to soil forming factors and process. Spatial variation in soil properties cause uneven patterns in soil fertility in turn crop growth, and use efficiency of externally applied resources. Application of variable rates of inputs needs partitioning of land units into homogeneous land management units (LMU), for production benefits and to minimize the adverse environmental impacts. The soil and site characteristics namely texture, depth and gravelliness, land use and climate are integrated to identify land units. Crop based production systems varied in different land units, production systems were super imposed on the delineated land units in GIS to identify the LMUs. Methodology was tested in Mysore district of Karnataka, where in 12 LMUs identified and delineated at district level. To verify the methodology, performance of crops vis-à-vis management practices followed in different LMUs was compared to plan appropriate land management decisions for current and future land use to ensure its sustainability.
\end{abstract}

Keywords: Land management unit, soil variability, GIS

\section{Introduction}

Soils are highly variable spatially due to the combined effects of physical, chemical, and biological weathering processes that operate with different intensities and at different scales (Goovaerts 1998) and that cause uneven patterns in soil fertility and crop growth, and decrease the use efficiency of inputs applied uniformly at the field scale. Uniform management of fields often results in overapplication of inputs in areas with high nutrient levels and under-application in areas with low nutrient levels (Ferguson et al., 2003). Application of variable rates of inputs has been proposed to avoid excessive use. Which needs partitioning of vast lands into homogeneous land management units (LMU). An approach to manage spatial variability within the region is the identification of LMUs, which are sub-divisions that have relatively homogeneous attributes in landscape and soil condition, and can be used to direct variable rate of input

*Corresponding Author Email: ramamurthy20464@yahoo.co.in
(Schepers et al. 2004; Ferguson et al. 2003) application which results in enhancing crop yield, input use efficiency, and reduce environmental impact (Khosla et al. 2002; Franzen et al., 2002).

Several studies have indicated that homogenous management zones/units could be used to develop nutrient maps for variable rate fertilizer application (Khosla and Alley 1999; Fleming et al. 2000; Naidu et.al. 2013). There are numerous methods for defining management units/zones, but most methods rely on spatial information sources that are stable or predictable over time and are related to crop yield (Doerge 1999). Soil properties (fertility, electrical conductivity, organic matter and texture, etc.), aerial photographs, topography factors (slope, gradient and elevation, etc.) and yield maps have all been suggested as logical basis to define homogenous zones in agricultural fields (Schepers et al. 2000, 2004) (Franzen et al. 2003). Parameters used for delineating LMUs vary with the 
situation or context based. India is having soil resource information at 1:1 million at national level, $1: 250 \mathrm{~K}$ at state level and few districts at 1:50K. Utility of this information for land use planning at different levels is most important. Khanna (1989) delineated Agro-climatic zones, with major emphasis on climate and physio-graphic units. He considered the constraints of soils in each region/zone for resource allocation at national level. Naidu et.al. (2015) proposed Agro-ecological zones using soil resource map at 1:250,000 scale, where emphasis has been given to length of growing period LGP for crop planning than soil-site factors. Growing period approach was adopted for land use planning at district level by Challa (1999). In this approach the temporal and spatial variations of the rainfall in different tehsils of the district and the spatial variations in soils and their characters were considered. Considering climate change impact, even within the tehasil more variability is observed in rainfall. Therefore, there is a need to develop methodology to identify and delineate relatively homogenous LMUs considering most important soil-site factors, which affect crop production, land use land cover, production systems and rainfall input at hobli or panchayat level. Land units having similar production systems, require similar management. This paper highlights the results of the study carried out in tropical south Deccan plateau represented by Mysore district of Karnataka.

\section{Materials and Methods \\ Studyarea}

Mysore district, situated in the southern part of Karnataka between $11^{\circ} 44^{\prime}$ and $12^{\circ} 39^{\prime}$ and $75^{\circ} 54^{\prime}$ and $77^{\circ} 08^{\prime}$, covering an area of $659300 \mathrm{ha}$. The district has a population of 29.95 lakhs (2011 census). It is divided into seven taluks (Fig.1); Mysore, Hunsur, Krishnarajanagar (K.R.Nagar), Periyapatna, Heggadadevanakote (H.D.Kote), Nanjangud and Tirumalakuda Narsipura (T. Narasipura).

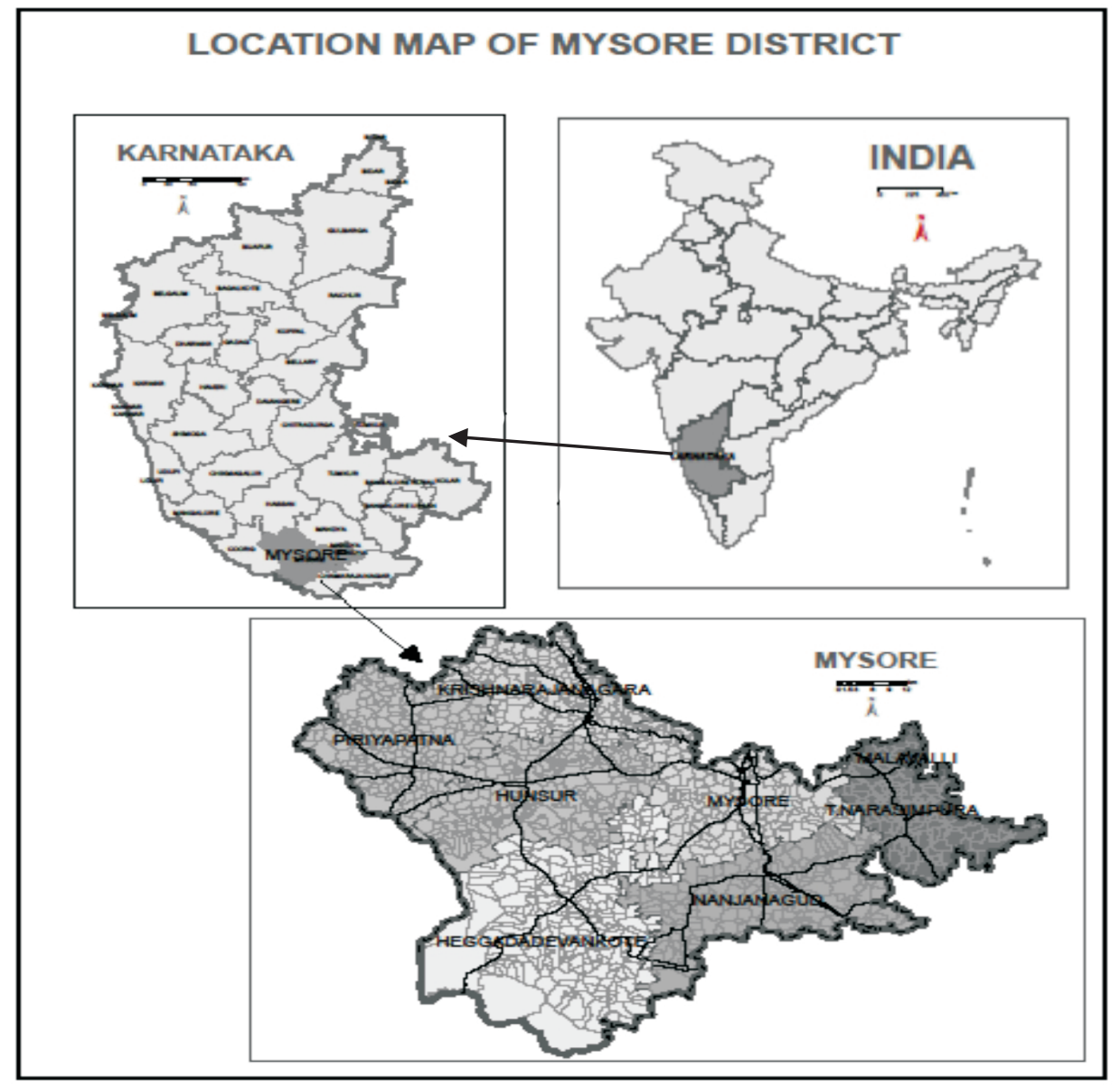

Fig. 1 Location map of study area 


\section{Geology}

The geological formations in the district are Archaean group, Proterozoic and Recent. Peninsular gneisses of Archaean period occur in all the taluks of the district and cover $80 \%$ area. It is composed of biotite gneiss, hornblende gneiss and other unclassified crystallines. Dharwar formations of lower precambrian consist of chlorite schist, hornblende-schist and talc schist, soap stone and magnasite and numerous economic minerals. Dharwarschist occurs in small elongated patches in all .the taluks of the district. The closepet granites and charnockites occur in Heggadadevanakote taluk to limited extent. Chamundigranite occurs in Mysore taluk. Various ultra basic dykes also occur in patches as intrusives.

\section{Physiography, Reflief and Drainage}

The district has part of Western Ghats, Malnad and South Deccan plateau. Major area is in South Deccan Plateau. The Malnad and Western Ghats area covers the south western and western part of the district in Heggadadevanakote, Hunsur and Periyapatna taluks. The elevation in Western Ghats and Malnad ranges from $991 \mathrm{~m}$ at Anechowkur in Periyapatna taluk to $739 \mathrm{~m}$ at Heggadadevanakote. The Western Ghat and Malnad area is drained by major rivers Cauvery and Kabini with tributaries of Lakshamanathirtha, Nagarahole and Nuguhole.
The South Deccan plateau was exposed for long ages of denudation under semi-arid climatic weathering cycles. Sheet wash and retreat of hill slopes are the major geomorphic processes responsible for present day landforms. The plateau surface has an elevation ranging from $650 \mathrm{~m}$ to $921 \mathrm{~m}$ above MSL, which mostly consists of undulating to gently sloping lands with dominant slopes of 3 to $8 \%$. The plateau region is drained by Kabini and Cauvery rivers. These rivers are generally flowing in east direction originating in Western Ghats. The drainage is sub-parallel and dendritic. The district has two reservoirs namely Krishnarajasagara and Kabini with dams built on Cauvery and Kabini rivers. The minor reservoir is Nugu located at Birval.

\section{Climate}

The climate is semi-arid. The mean annual rainfall is $803 \mathrm{~mm}$ of which $72 \%$ is received during the southwest monsoon (June to October). The annual rainfall ranges from 780 to 840 $\mathrm{mm}$ in different taluks (Table.1). and highest in October month. The mean monthly temperatures (Table 1) range from 22 to $28^{\circ} \mathrm{C}$. The minimum temperature is recorded in December $\left(22^{\circ} \mathrm{C}\right)$ and the maximum in April $\left(28^{\circ} \mathrm{C}\right)$. Potential evapotranspiration (PET) is about $1531 \mathrm{~mm}$. The evapotranspiration demand is high during March (165 $\mathrm{mm} / \mathrm{month}$ ) and is lowest during November (106mm / month). 


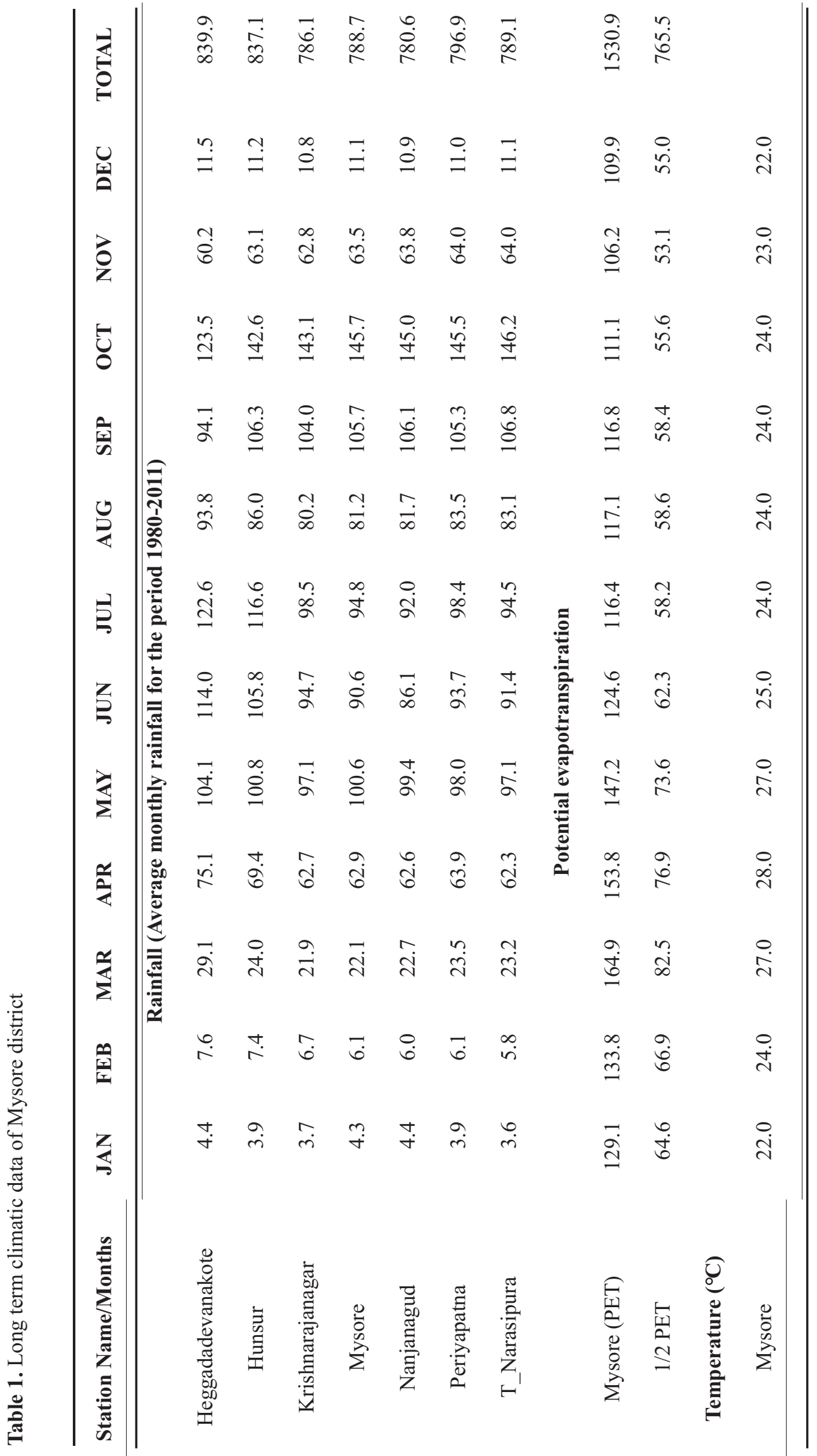




\section{Methodology}

Mysore district soil map at $(1: 50,000)$ scale was used (NBSS\&LUP, 2007). Important soil properties considered for grouping of soil map units are landform, texture, depth and gravellines, which significantly influence crop production and 95 soil mapping units were re-grouped into 15 similar soil units(Fig 2) which respond in similar manner for given management. The delineation was updated and rectified using satellite data. Land use and land cover map received from Karnataka State Remote Sensing Application Centre had 27 map units, which was further grouped into 7 map units (Fig 3): Irrigated agricultural lands, rainfed agricultural lands, forest lands, industrial and mining areas, habitations, water bodies and miscellaneous land.

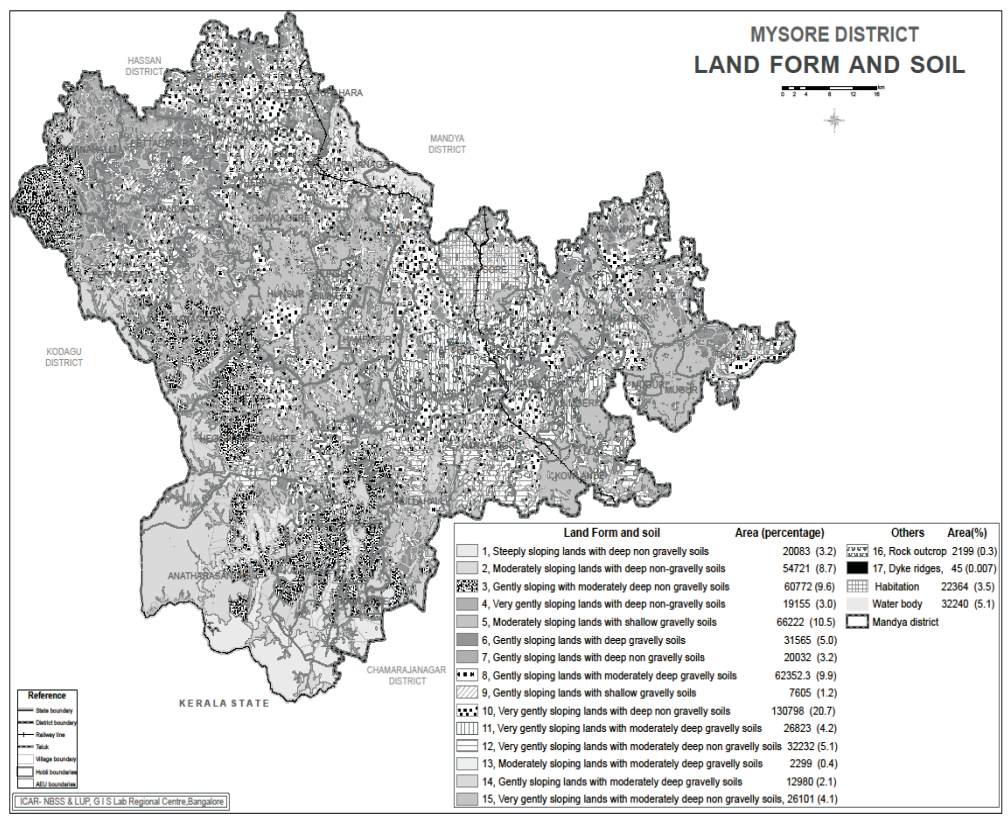

Fig. 2 Interpreted soil map of Mysore district

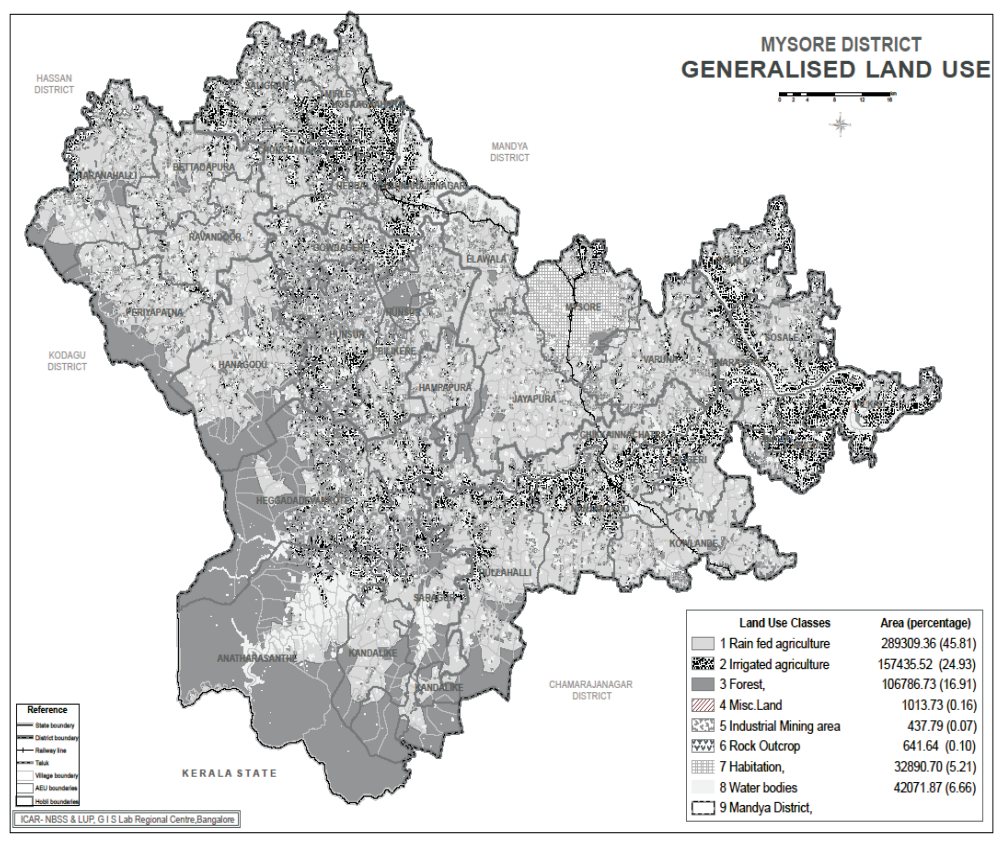

Fig. 3 Interpreted land use /land cover map of Mysore district 
Agro-ecological analysis of the district was carried out by collecting weekly rainfall data from 44 rain-gauge locations across the district for the period of 25 years. The rainfall analysis included weekly average rainfall, average pre-monsoon rainfall, average post-monsoon rainfall, south west and north-east monsoon rainfall, probability of moderate and severe drought, initial and conditional probability of wet and dry weeks, soil water balance, moisture adequacy index and LGP at $75 \%$ probability of a week. Based on these parameters four Agro-Ecological Units (AEU) were delineated in the district (Fig 4). All the taluks of the district were traversed to verify soil and land use in terms of rainfed or irrigated lands and documentation of different cropping systems. Step-wise overlay (Fig 5) of soil, land use and land cover and agro-ecological units map in GIS frame work resulted in land units (LU) map with 96 units (Fig. 6). Farming system data collected from all the major land units resulted in five major production systems in the district (Table 2).

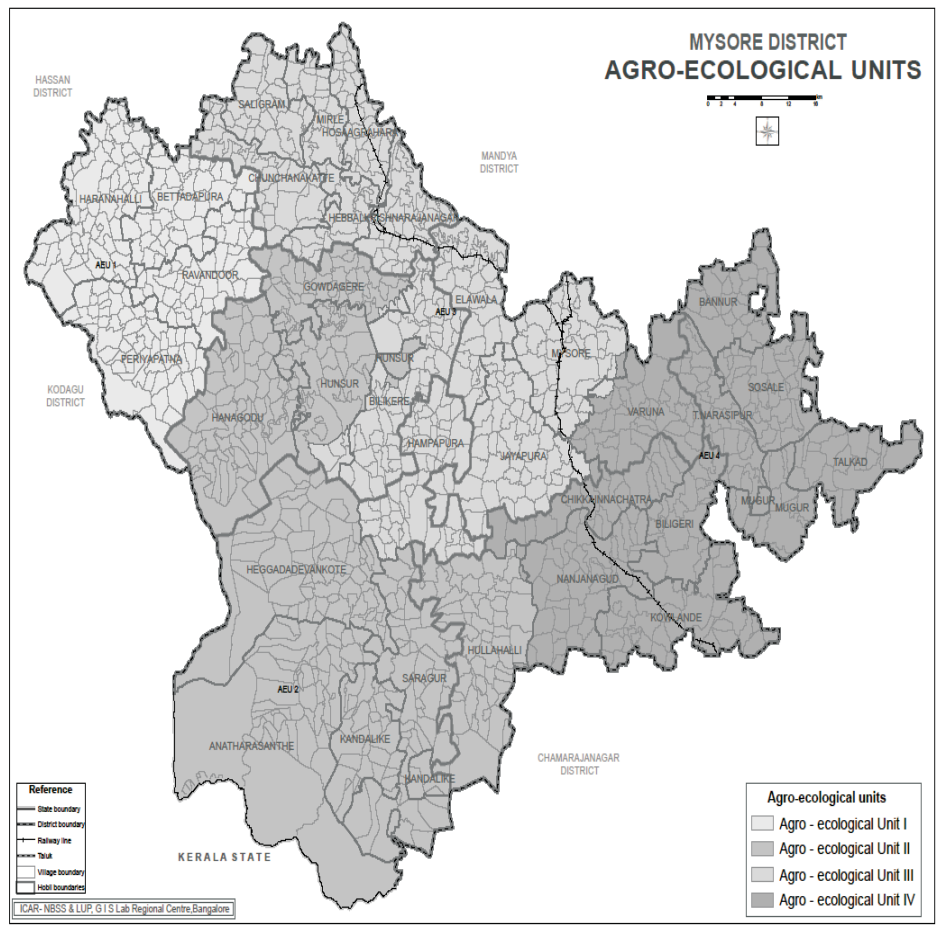

Fig. 4. Agro-ecological unit map of Mysore district

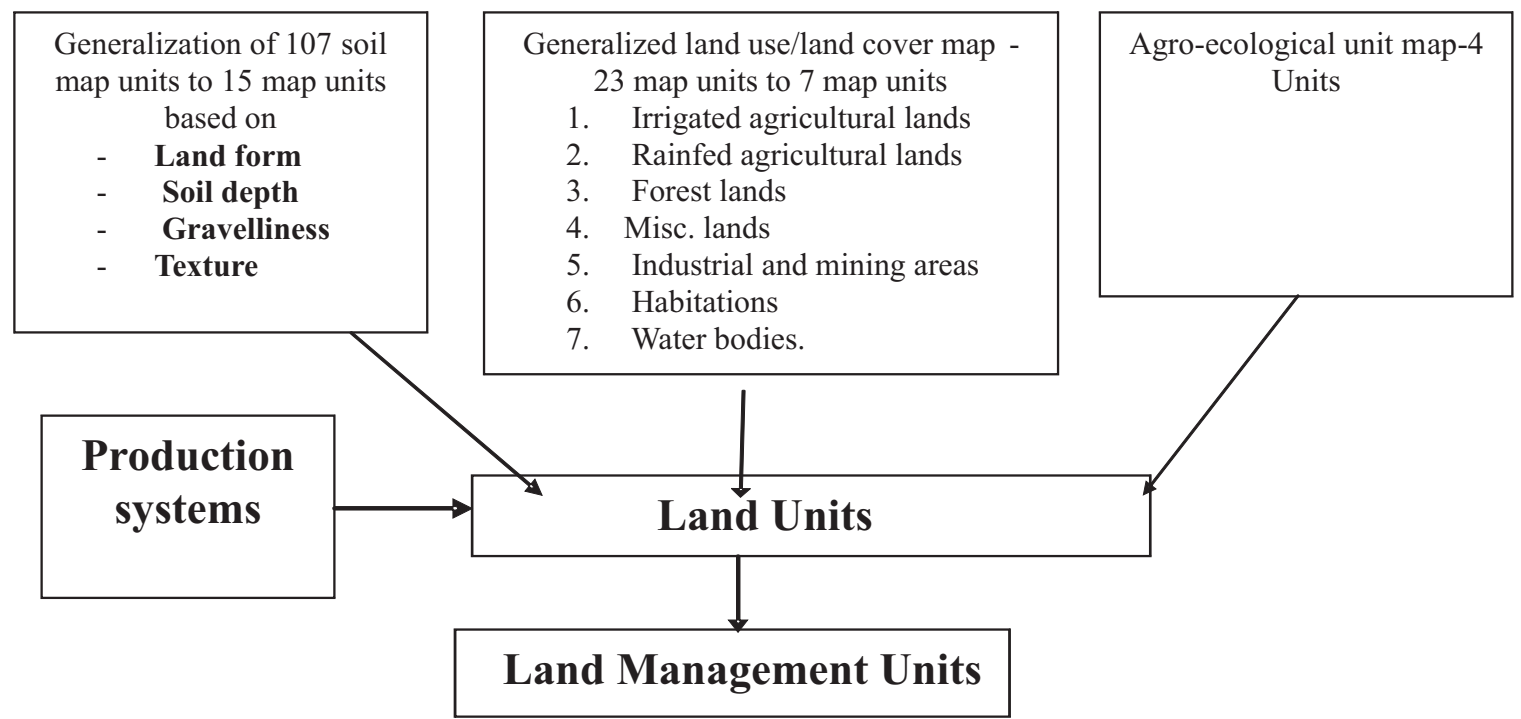

Fig. 5 Concept and demarcation of Land Management Units 
Table 2. Major production systems in Mysore district

S. No. Production systems

$$
\text { Irrigated }
$$

1. Rice and sugarcane production system (Dairy)

2. Rice and maize production system (Dairy + sericulture)

\section{Rainfed}

3. Tobacco-finger millet/Pulses based production system

4. Cereal (finger millet, sorghum, Maize) based production system

5. Cotton and cereal based production system

In rainfed situation, integrated mixed farming system is dominant (2-3 cows/buffaloes + pair of bullocks, $8-10$ sheep/goats)

Land units were further grouped into homogenous land management units (LMUs) based on similar farming system/cropping systems existing in the different land units.
Methodology used for identifying the LMUs is presented in the flow diagram (Fig 5). 12 LMUs were delineated in Mysore district (Fig 6).

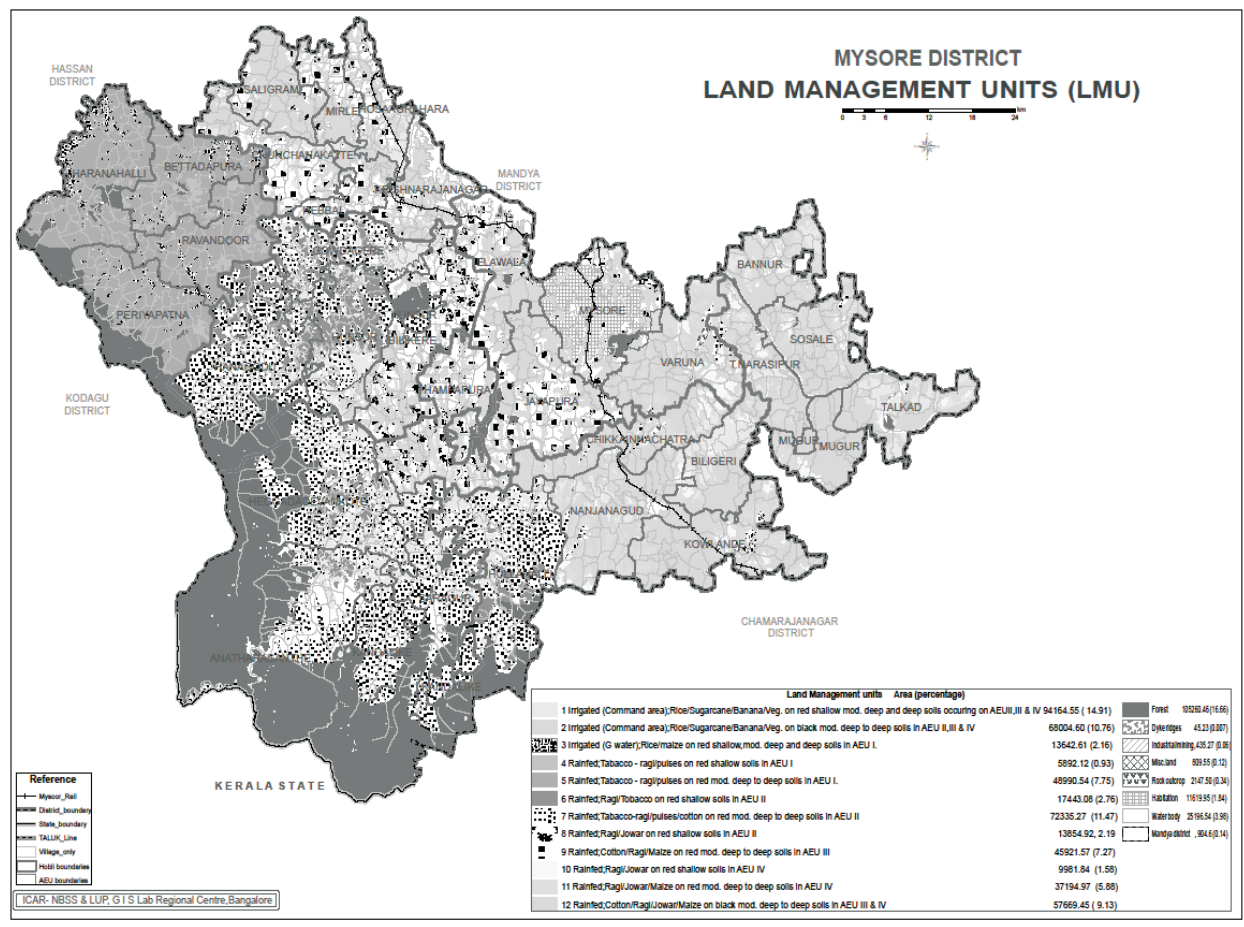

Fig. 6. Land management units of Mysore district

To verify the performance of crops in different LMUs, crop yield data was collected from 342 farmers covering all the LMUs and standard deviation was calculated within the LMU to know the variability of crop yield.

\section{Results and Discussion}

In Mysore district 12 LMUs were delineated (Table 3), of which 3 are under irrigated and 9 under rainfed agriculture. The major cropping systems and characteristics of LMUs are presented in table 3. LMU1 and 2 are canal irrigated areas and LMU3 is ground water irrigated. Therefore, one can find rice in LMU1 and 2 in all the seasons or minimum two seasons except tail end. All irrigated LMUs occour gentle to very gentle slop. Soils are moderately deep to deep in LMU 2 and shallow to deep in LMU 1 and LMU 3. Non-gravelly and sandy clay soils are dominant in LMU 2 and gravelly sandy clay loams in LMU 1 and LMU 3. 
Table 3. Characteristics of Land Management Units

\begin{tabular}{|c|c|c|c|c|c|c|}
\hline LMU & $\begin{array}{l}\text { Major crops/Cropping } \\
\text { systems }\end{array}$ & $\begin{array}{l}\text { Land } \\
\text { Form }\end{array}$ & $\begin{array}{l}\text { Soil depth } \\
(\mathrm{cm})\end{array}$ & $\begin{array}{l}\text { Gravel } \\
\text { li-ness }\end{array}$ & Texture & LGP \\
\hline \multicolumn{7}{|l|}{ Irrigated } \\
\hline $\begin{array}{l}\text { 1. Irrigated (Command area), red } \\
\text { soils, shallow, moderately deep } \\
\text { and deep soils occurring on AEU } \\
\text { II,III \& IV }\end{array}$ & $\begin{array}{l}\text { Pulses-rice, Rice -rice- } \\
\text { rice, Rice -rice, Rice, } \\
\text { Sugarcane, Finger millet, } \\
\text { Banana, Vegetables, } \\
\text { Mulberry }\end{array}$ & $\begin{array}{l}\text { G-VG } \\
\text { slope }\end{array}$ & $>50$ & $25-35 \%$ & $\begin{array}{l}\text { Sandy } \\
\text { clay } \\
\text { loam }\end{array}$ & - \\
\hline $\begin{array}{l}\text { 2. Irrigated (Command area), } \\
\text { black soils, moderately deep to } \\
\text { deep soils in AEU II, III and IV }\end{array}$ & $\begin{array}{l}\text { Pulses-rice, Rice-rice- } \\
\text { rice, Rice-rice, Rice, } \\
\text { Sugarcane, Finger millet- } \\
\text { rice/pulses, Rice-black } \\
\text { gram/green gram }\end{array}$ & $\begin{array}{l}\text { VG } \\
\text { sloping }\end{array}$ & $>100$ & $\begin{array}{l}\text { Non- } \\
\text { gravelly }\end{array}$ & $\begin{array}{l}\text { Sandy } \\
\text { clay }\end{array}$ & - \\
\hline $\begin{array}{l}\text { 3. Irrigated (ground water), red } \\
\text { soils, shallow, moderately deep } \\
\text { and deep soils in AEU I }\end{array}$ & Rice, Maize, Mulberry & $\begin{array}{l}\text { G-VG } \\
\text { sloping }\end{array}$ & $\begin{array}{l}>50 \\
\text { Black } \\
\text { soils }\end{array}$ & $25-35 \%$ & $\begin{array}{l}\text { Sandy } \\
\text { clay } \\
\text { loam }\end{array}$ & - \\
\hline \multicolumn{7}{|l|}{ Rainfed } \\
\hline $\begin{array}{l}\text { 4. Rainfed, tobacco and } \\
\text { cereal/pulses (double cropping) } \\
\text { based production s ystems on red } \\
\text { shallow soils in AEU I }\end{array}$ & $\begin{array}{l}\text { Tobacco-finger } \\
\text { millet/Pulses, Finger } \\
\text { millet+field bean, Horse } \\
\text { gram, Maize }\end{array}$ & $\begin{array}{l}\text { Mod. } \\
\text { sloping }\end{array}$ & $25-50$ & $>35 \%$ & $\begin{array}{l}\text { Loamy } \\
\text { sand }\end{array}$ & $\begin{array}{l}120-190 \\
\text { days }\end{array}$ \\
\hline $\begin{array}{l}\text { 5. Rainfed, tobacco and cereal } \\
\text { (double cropping) based } \\
\text { production systems on red } \\
\text { moderatelly deep to deep soils in } \\
\text { AEU I }\end{array}$ & $\begin{array}{l}\text { Tobacco-finger } \\
\text { millet/Pulses, } \\
\text { Maize/cowpea-finger } \\
\text { millet, finger millet }+ \text { field } \\
\text { bean/Red gram, Maize, } \\
\text { G.nut }\end{array}$ & $\begin{array}{l}\text { Mod.-G } \\
\text { sloping }\end{array}$ & $>50$ & $25-35 \%$ & $\begin{array}{l}\text { Sandy } \\
\text { loam }\end{array}$ & $\begin{array}{l}120-190 \\
\text { days }\end{array}$ \\
\hline $\begin{array}{l}\text { 6. Rainfed, finger millet based } \\
\text { production systems on red } \\
\text { shallow soils in AEU II }\end{array}$ & $\begin{array}{l}\text { Finger millet, sorghum, } \\
\text { Hose gram, cotton, } \\
\text { Tobacco-Horse } \\
\text { gram/Field bean }\end{array}$ & $\begin{array}{l}\text { Mod. } \\
\text { sloping }\end{array}$ & $25-50$ & $>35 \%$ & $\begin{array}{l}\text { Sandy } \\
\text { clay } \\
\text { loam }\end{array}$ & $\begin{array}{l}150-170 \\
\text { days }\end{array}$ \\
\hline $\begin{array}{l}\text { 7.Rainfed, tobacco-finger } \\
\text { millet/pulses and cotton based } \\
\text { production systems on red } \\
\text { moderately deep to d eep soils in } \\
\text { AEU II }\end{array}$ & $\begin{array}{l}\text { Tobacco-finger } \\
\text { millet/horse gram/field } \\
\text { bean/cowpea, } \\
\text { Sesame/cowpea-finger } \\
\text { millet, Cotton, Maize, } \\
\text { G.nut }\end{array}$ & $\begin{array}{l}\text { G-VG } \\
\text { sloping }\end{array}$ & $>50$ & $25-35 \%$ & $\begin{array}{l}\text { Loamy } \\
\text { sand }\end{array}$ & $\begin{array}{l}150-170 \\
\text { days }\end{array}$ \\
\hline $\begin{array}{l}\text { 8. Rainfed, finger millet based } \\
\text { production systems on red } \\
\text { shallow soils in AEU III }\end{array}$ & $\begin{array}{l}\text { Finger millet, Finger } \\
\text { millet }+ \text { Field bean/Red } \\
\text { gram, sorghum, Cotton, } \\
\text { Tobacco, Maize, Horse } \\
\text { gram }\end{array}$ & $\begin{array}{l}\text { Mod.-G } \\
\text { sloping }\end{array}$ & $25-50$ & $>35 \%$ & $\begin{array}{l}\text { Sandy } \\
\text { clay } \\
\text { loam }\end{array}$ & $\begin{array}{l}90-120 \\
\text { days }\end{array}$ \\
\hline $\begin{array}{l}\text { 9. Rainfed, cotton and finger } \\
\text { millet based production systems } \\
\text { on red moderately deep to deep } \\
\text { soils in AEU III }\end{array}$ & $\begin{array}{l}\text { Cotton, Finger millet+ } \\
\text { Red gram, sorghum, } \\
\text { Tobacco-finger millet/ } \\
\text { Field bean / Horse gram, } \\
\text { Maize }\end{array}$ & $\begin{array}{l}\text { G-VG } \\
\text { sloping }\end{array}$ & $>50$ & $25-35 \%$ & $\begin{array}{l}\text { Sandy } \\
\text { clay } \\
\text { loam }\end{array}$ & $\begin{array}{l}90-120 \\
\text { days }\end{array}$ \\
\hline $\begin{array}{l}\text { 10.Rainfed cereal-based } \\
\text { production systems on red } \\
\text { shallow soils in AEU IV }\end{array}$ & $\begin{array}{l}\text { Finger millet }+ \text { field bean/ } \\
\text { Red gram, sorghum, } \\
\text { Horse gram, Maize }\end{array}$ & $\begin{array}{l}\text { Mod.-G } \\
\text { sloping }\end{array}$ & $25-50$ & $>35 \%$ & $\begin{array}{l}\text { Loamy } \\
\text { sand }\end{array}$ & $\begin{array}{l}90-100 \\
\text { days }\end{array}$ \\
\hline $\begin{array}{l}\text { 11. Rainfed, cereal-based } \\
\text { production systems on red } \\
\text { moderately deep to deep soils in } \\
\text { AEU IV }\end{array}$ & $\begin{array}{l}\text { Sesame/cowpea-Finger } \\
\text { millet+ Field bean, } \\
\text { sorghum, Cotton, Maize, } \\
\text { Groundnut, Horse gram, } \\
\text { Coriander }\end{array}$ & $\begin{array}{l}\text { G-VG } \\
\text { sloping }\end{array}$ & $>50$ & $25-35 \%$ & $\begin{array}{l}\text { Sandy } \\
\text { clay } \\
\text { loam }\end{array}$ & $\begin{array}{l}\text { 90-100 } \\
\text { days }\end{array}$ \\
\hline $\begin{array}{l}\text { 12. Rainfed, cotton and cereal } \\
\text { based production systems on } \\
\text { moderately deep to deep black } \\
\text { soils in AEU III \& IV }\end{array}$ & $\begin{array}{l}\text { Cotton, Sesame/cowpea - } \\
\text { finger millet, Finger } \\
\text { millet+ Field bean, } \\
\text { sorghum, Red gram, } \\
\text { Tobacco-Finger } \\
\text { millet/field bean/ Horse }\end{array}$ & $\begin{array}{l}\text { VG } \\
\text { sloping }\end{array}$ & $\begin{array}{l}>100 \\
\text { Black } \\
\text { soils }\end{array}$ & $\begin{array}{l}\text { Non } \\
\text { gravelly }\end{array}$ & clay & $\begin{array}{l}\text { 90-120 } \\
\text { days }\end{array}$ \\
\hline
\end{tabular}

Note: $\mathrm{G}=$ Gently sloping (3-5\%); VG=Very gently sloping (1-3\%); Mod-Moderately sloping (5-10\%) 
Delineated LMU 4 to 11 in rainfed conditions cover red soils, where as LMU 12 is black soil (Table 3). Very gently sloping with moderately deep to deep non-gravelly clayey black soils having 90-120 days LGP are the dominant characteristics of LMU 12. LMU 4, LMU 6, LMU 8 and LMU 10 are associated with shallow gravelly sandy loam soils with LGP of 120-190 days, 150-170 days, 90-120 days and 90-100 days respectively, whereas LMU 5, LMU 7, LMU 9 and LMU 11 had moderately deep to deep sandy clay loam soils with LGP of 120-190 days, 150-170 days, 90-120 days and 90-100 days respectively.

LMUs were evaluated for their suitability to major crops namely rice, finger millet, cotton and tobacco by matching LMUs with crop requirements (Naidu et. al., 2006). LMU 2 was found highly suitable for rice, LMU 7; for finger millet; LMU 5 and 7 for tobacco. LMU 7 was moderately suitable for cotton. LMU 12 has advantage to grow cotton, redgram, maize, cotton intercropped with redgram and tobacco inter cropped with field bean as soils are clayey black soils with 90-120 days LGP. Bt cotton performs better than $G$. hirusutum hybrids. Though, LMU 4 and LMU 7 have favourable LGP for tobacco-based cropping systems due to soil limitation in LMU 4 tobacco productivity is poor and finger millet + field bean is generally followed in this LMU. However, those farmers having irrigation facilities are successfully growing tobacco with high input with marginal net profit. Similarly, cereal-based production system is more remunerative than tobacco or cotton in LMU 6. Double cropping of tobacco followed by cereals or pulses prevail in LMU 5 due to favourable soil (moderately deep to deep) and growing period (120-190).

Rice productivity varied in farmer's fields from 26 to 54 $\mathrm{qha}^{-1}$, finger millet 22 to $34 \mathrm{qha}^{-1}$, tobacco 15 to $17 \mathrm{qha}^{-1}$ and cotton 10 to $13.5 \mathrm{qha}^{-1}$ in different LMUs. 


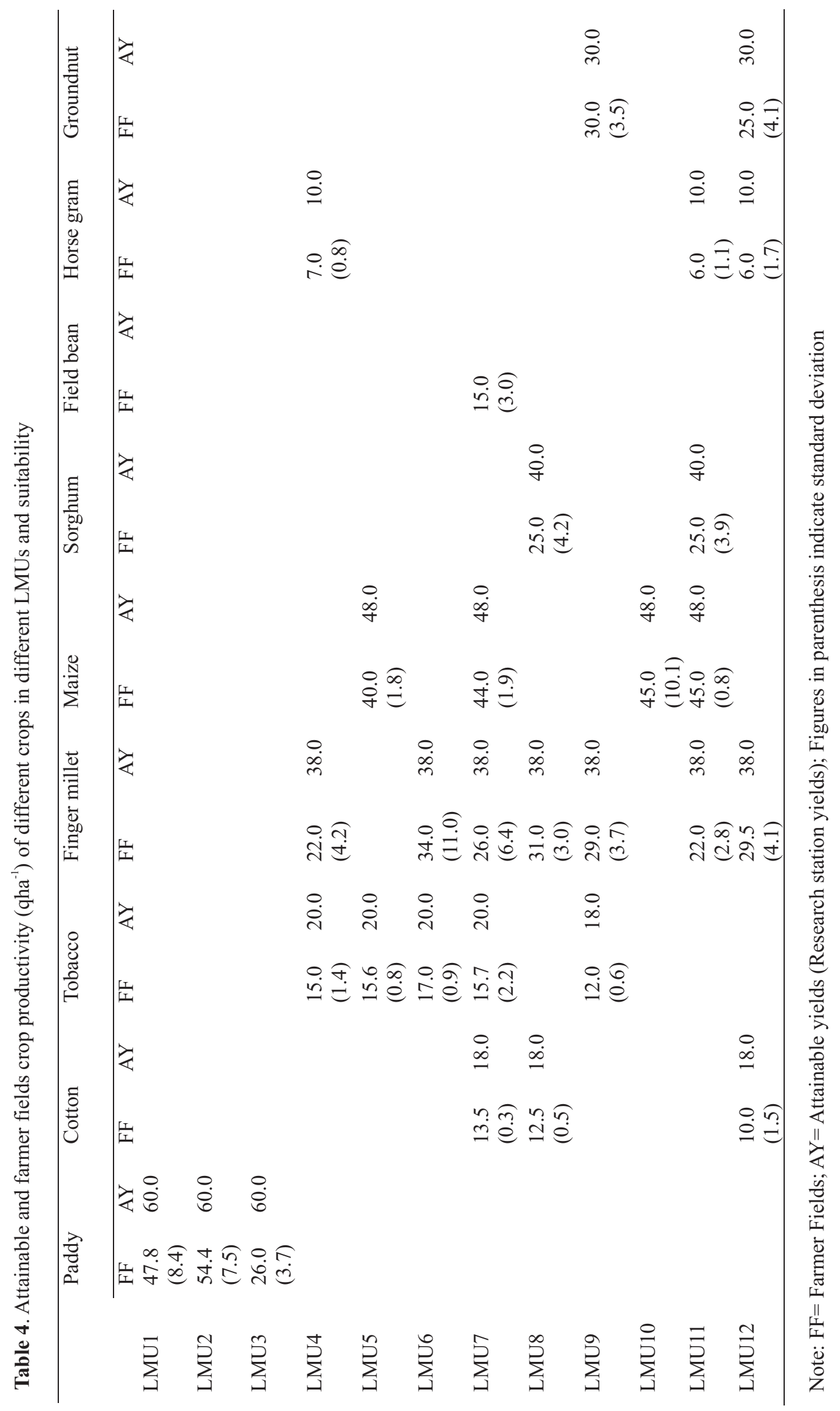


In irrigated LMUs productivity variation was more within the LMU due to varied management practices like variety agroinputs and water management. Among the rainfed LMUs, finger millet productivity in LMU 6 and maize productivity in LMU 10 had higher deviation from mean yield of the LMUs(Table 4). Rice yield of $54 \mathrm{qha}^{-1}$ recorded in LMU 2 was almost on par with research station productivity. Highest finger millet yield of $34 \mathrm{qha}^{-1}$ recorded in LMU 6 which was slightly lower than the research station yield (38 qha $\left.^{-1}\right)$. Tobacco yield in LMU 6 was almost equal to research station yield ( $20 \mathrm{q} / \mathrm{ha})$. Cotton yields were low than the research station yields in all the LMUs. In most of the LMUs, nitrogen application was more than the recommended dose except LMU 3 for rice and LMU 4 for finger millet, whereas, in tobacco both $\mathrm{N}$ and $\mathrm{P}$ applications were more than the recommended. This indicated that farmers were applying higher doses of fertilizers, which may lead to adverse effects on soil health and also increases the cost of production of crops. Under rainfed situation, though LMU 6 was rated only marginally suitable for most of the crops evaluated, however, actual productivity of crops was comparatively better. Better performance of crops is attributed to high input usage ( $\mathrm{N}$ and $\mathrm{K}$ ) and protective irrigation facilities. The inherent soil and climate limitations can be overcome by better management practices.

As LMUs are homogenous with respect to climate and soil. The variation in crop performance in some LMUs was due to differences in management practices adopted by farmers. To improve the efficiency of inputs and productivity of crops, LMUs serve as alternative functional units instead of zones. LMU concept within the district helps development departments, private sector players and research and development organizations to prioritize the problem and find the solutions and also to allocate required management inputs to farming community, which reduces the cost of production and enhance the profitability. Similar observations were made by Schepers et. al. (2004) and Ferguson et. al. (2003). The utility of the LMUs at a more detailed scale for supporting farm management decisions is still being tested.

\section{Conclusion}

Identification and delineation of homogenous LMUs helps in proper utilization bio-physical resources and enhance the productivity of crops and input use efficiency. Methodology was developed to delineate the LMUs at district level in Deccan plateau by considering soil variability, climate and land use land cover. Variability in soil properties such as texture, soil depth, landform and gravelliness are found to have significant bearing on crop productivity besides length of growing period. Productivity of crops varied across the LMUs indicating the need for different management strategies. The experience of the Mysore district suggests that the LMU approach could be developed as a multiscale analytical platform to support an adaptive land-use planning process, and could also be regarded as an effective support tool for using and managing Deccan plateau resources

\section{Acknowledgements}

The contributions of Mysore district administration for their help in providing necessary secondary data during the study are duly acknowledged.

\section{References}

Challa, O. (1999). Land resource evaluation for district level planning - an approach. Journal of The Indian Society of Soil Science 47, 298-304.

Doerge, T. (1999). Defining management zones for precision farming. Crop Insights 8(21), 1-5.

Fleming, K.L. Westfall, D.G., Wiens, D.W. and Brodah, M.C. (2000). Evaluating farmer developed management zone maps for variable rate fertilizer application. Precision Agriculture 2, 201-215.

Ferguson, R.B., Lark, R.M. and Slater, G.P. (2003). Approaches to management zone definition for use of nitrification inhibitors. Soil Science Society of American Journal 67, 937-947.

Franzen, D.W., Hopkins, D.H., Sweeney, M.D., Ulmer, M.K. and Halvorson, A.D. (2003). Evaluation of soil survey scale for zone development of site-specific nitrogen management. Agronomy Journal 94, 381-389. 
Goovaerts, P. (1998). Geostatistical tools for characterizing the spatial variability of microbiological and physico-chemical soil properties. Biology. Fertilizers Soils 27, 315-334.

Khanna, (1989). Agro-climatic regional planning: an overview (unpublished). Planning Commission, New Delhi, pp. 144.

Khosla, R. and Alley, M.M. (1999). Soil-specific management on Mid-Atlantic coastal plain soils. Better Crops with Plant Food 83 (3), 6-7.

Khosla, R., Fleming, K., Delgado, J.A., Shaver, T.M. and Westfall, D.G. (2002). Use of site specific management zones to improve nitrogen management for precision agriculture. Journal of Soil and Water Conservation 57 (6), 513-518.

Naidu L.G. K., Ramamurthy, V., Challa, O., Rajendra Hegde and Krishnan, P. (2006). Manual soil-site suitability criteria for major crops. Tech. Bull. No. 129, NBSSLUP, Nagpur(India), p. 118.
Naidu L.G.K., Ramamurthy V., Niranjana K.V., Satyavathi P.L., Srinivas S., Dhanorkar B.A., Ravindra Chary G. and Reddy, R.S. (2015). Evaluation of regional bench Mark soils and Agrotechnology Transfer-A Case study of A.P. J. of the Indian Society of Soil Science 63(2),144-158.

Naidu L.G.K., V. Ramamurthy, S.Srinivas, R.S.Reddy and Dipak Sarkar. (2013). Need for developing user friendly soil maps: A case study of Andhra Pradesh. Agropedology 23(1): 30-35.

NBSS\&LUP. (2007). Soil resource inventory of Mysore district. NBSS Publ. No.1011

Schepers, J.S., Schlemmer, M.R. and Fergunson, R.B. (2000). Site-specific considerations for managing phosphorus. Journal of Environmental Quality 29, 125-130.

Schepers, A.R., Shanahan, J.F., Liebig, M.K., Schepers, J.S., Johnson, S.H. and Luchiari Jr., A. (2004). Appropriateness of management zones for characterizing spatial variability of soil properties and irrigated corn yields across years. Agronomy Journal 96, 195-203.

Received: July 2016

Accepted: December 2016 